\title{
上腕動脈圧迫解除時における血管壁の柔軟性の評価
}

\author{
吉川和博
}

東京電機大学大学院理工学研究科 電子情報工学専攻

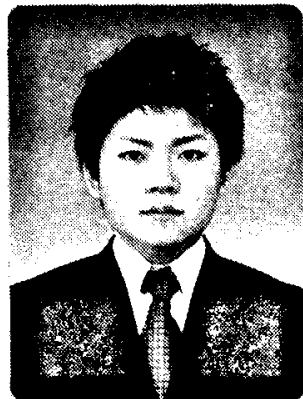

1. はじめに

近年, 健康維持への関心が高まり，家庭内において自分の 健康を把握できる方法・装置の開発が望まれている.また, 動 脈硬化症の進行状況, 特に動脈壁の力学的状態(柔軟性)を 検査する様々な方法があるが，専門知識や高価な装置を必 要とする ${ }^{1) ， 3)}$.そのため生活習慣病が起因となる動脈硬化の 状態を家庭でモニタリングすることは難しい。

そこで本研究では，家庭でも広く使用されている聴診法によ る血圧測定を応用して，血管壁の柔軟性を推定する方法を提 案した.本稿では，提案する手法に基づいて測定システムを開 発し，模擬循環回路を用いた評価および，年齢の異なる被 験者で実際に測定を行った結果について報告する.

\section{2. 原理}

聴診法で血圧測定する際には，上腕にカフ(圧迫带)を装 着する.このカフで上腕を圧迫して血流を止め, その圧迫を 徐々に解除する過程で, 心拍に同期してコロトコフ音が発生 する ${ }^{2}$.この時, カフで腕を圧迫する圧力を $\mathrm{P}_{\mathrm{O}}$ ，血圧が血管壁 に加える圧力を $\mathrm{P}_{\mathrm{i}}$ とする.血が流れる時にコロトコフ音が発生 する事から， $\mathrm{P}_{0}<\mathrm{P}_{\mathrm{i}}$ となった際，音が発生すると考えられるこ の音が 2 箇所で計測される時間差を虚脱動脈復㷌時間： CART (Collapsed Artery Return Time) と定義したここの CART は，血管壁が柔軟であるほど，潰れた血管が膨らむ時間は短 くなると想定し, CART の差から柔軟性を推定する手法とした。

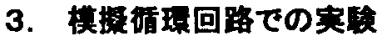

\section{1 方法}

Fig.1に示した循環回路は，拍動ポンプ $(\mathrm{H})$ ，

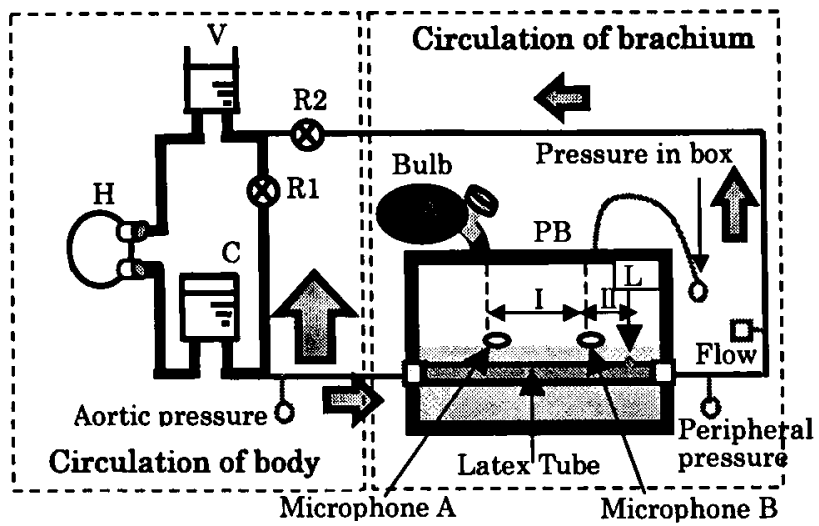

Fig.1 Circulatory simulator
コンプライアンスタンク $(\mathrm{C})$ ，リザーバタンク $(\mathrm{V})$ ，腕末梢抵抗 （R1），体循環末梢抵抗(R2)，上腕を模擬した箱 (PB) で構成 した.このシステムに，特性の異なるラテックス管 $\alpha$ (柔らかい 管)または $\beta$ (硬い管)を接続し，潰れた管が膨れる際，管上2 箇所から音をマイクロフォン（（株）秋月電子：BCM-302 -80））で計測し，CARTを求めた.

この時, 2つのマイクロフォン間の距離 I は 7.5[cm]一定とし, マイクロフォン B から距離 II 1.0[cm]離れた管壁の変位を、レ 一ザー変位計（松下電工株式会社：ANR1250）で計測し た.また，模擬循㻴回路の流量，圧力の設定值は，健常者の 血行動態を模擬した值とした。

\section{2 結果}

両方のマイクロフォンで最初に音が計測された時を First Sound として, CART を求めた.また各 CART は, ラテックス管 に加わる外圧(PB の内圧)を解除してゆく間, 2つのマイクロフ オンで音が計測される範囲全てにおいて求めた.2種類のラテ ックス管 $\alpha$ と $\beta$ にて求めた CARTを Fig.2 に示した.

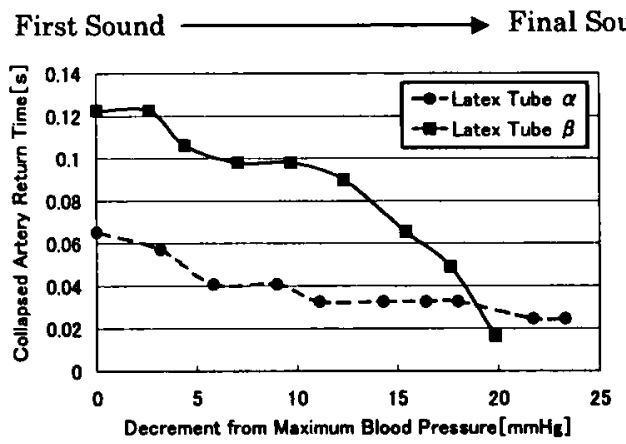

Fig.2 Comparison of CART measured from two latex tubes

Fig.2 より, 2 種類のラテックス管ともに, PB 内の圧が減圧さ れるにつれて, CARTが短くなった.また, ほぼ全てのCARTに おいて，管 $\beta$ の方が，管 $\alpha$ よりも長い事が確認できた.また， Fig.3に示した,レーザー変位計で計測した波形から，管壁変 位の速度・振幅が，管 $\alpha$ と $\beta$ で異なる部分が確認された.この 事は，管壁の柔軟性(管特性)が異なる事で, 变位の速度・振 幅に差が生じる事を示していると考えられる.

以上の事功，血管壁の柔軟性の差は，CART の差として 求める事ができると考えられる. 


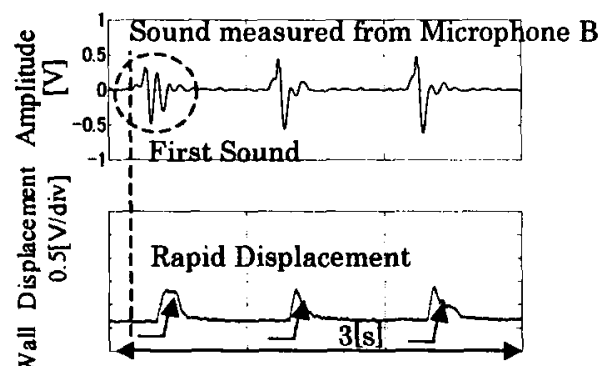

(a) Measuring Waveform from latex tube $\alpha$

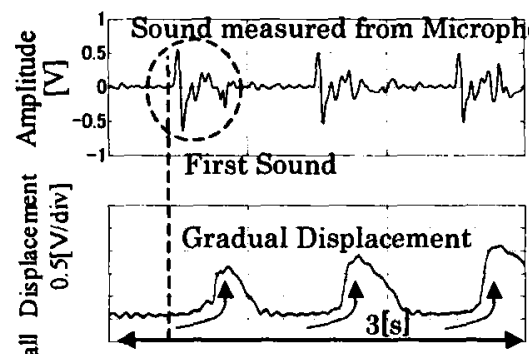

(b) Measuring Waveform from latex tube $\beta$

Fig.3 Comparison of Wall Displacement between Two Latex Tube

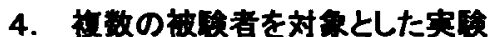

\section{1 方法}

計測システムとしては，自動血圧計（健太郎 BP203RVII， 日本コーリン(株)), 上腕動脈の音を計測するためのマイク 2 個, 腕に加わる圧力変化(外圧の変化)を得るための圧力セン サーとデータを取り込むPCから楎成した.音を計測するマイク は, 上腕動脈上の2筒所に皮店を介して固定し，1つは时から $2.5[\mathrm{~cm}]$ の位置 (一般に聴診法でコロトコフ音を計測する部 位)に，そこから $7.5[\mathrm{~cm}]$ 離して 2 つ目のマイクを固定した.

自動血圧計で被験者の血圧を計測する際に2個のマイクか ら得られる音を計測した.計測の間隔には 5 分間のインターバ ルを挟み, 3 回の計測を行った.被験者として 20 代 15 名と 50 代以上 7 名を対象とし，2 箇所で計測される音からCARTを求 め, 比較した。

\section{2 枚数の被駼者における CART の比较}

Fig.4に 20 代 3 名, 50 代以上 3 名において, 2 简所を伝播 する時間差の変化の一例を示した. Fig.4より, 全ての被験者 において, カフによる圧迫圧が减るにつれて, CART が短くな った.また, 第一音から求めた CART に着目すると, 高齢者に なるほど, CART が長くなる傾向にある事が確認できる.

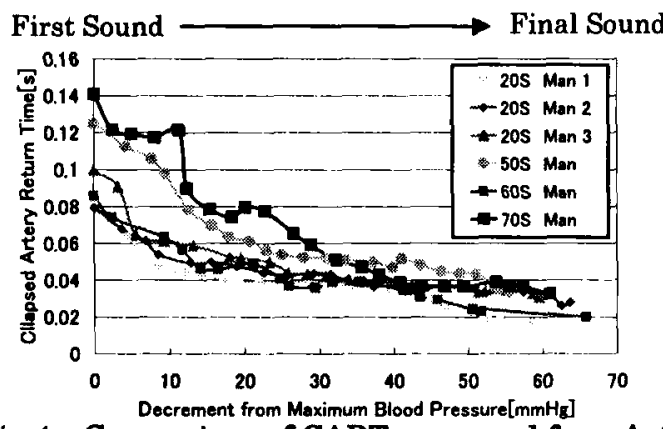

Fig.4 Comparison of CART measured from Artery

\section{3 考察}

年齢による差が生じると考えられる First Sound から求めた CART を, 20 代と 50 代以上に分けた 2 グルーブ分けて， CART の平均を求めた.また, 被験者による差が一番ないと考 えられる Final Sound から求めた CARTを, 2 グループ分け, CART の平均を求めた Fig.5 に示した.

20 代と 50 代以上に分けて求めた CART の平均值估, First Sound から求めた平均值に差があり, Final Sound から求めた 平均値には差がないことがわかった.また，有意水準 5\%で検 定を行ったところ, First Sound から求めた CART において, 2 グループ間の平均值に有意差が認められた.

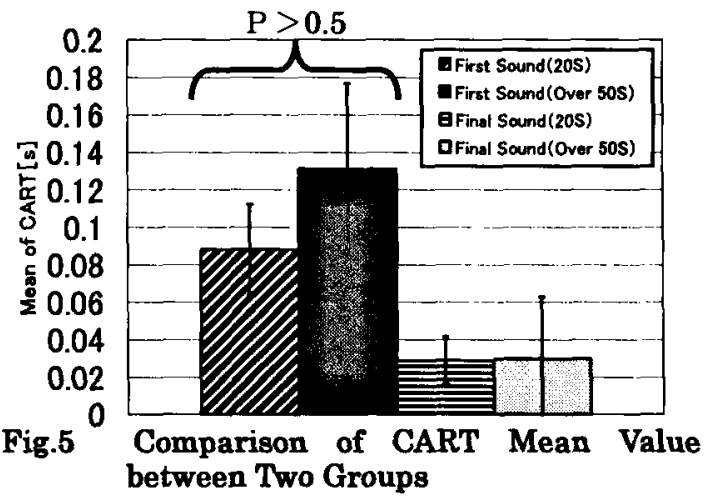

5. 梌討

年をとると，血管の柔軟性は失われる゙2.つまり，潰れにくく， 膨れにくい管になる.この事から、ラテックス管 $\beta$ の方が, 高齢 者の血管に相当すると考えられるここで，模擬での検討により， 管壁が硬いほど, 潰れたラテックス管が嬄れる際の変位速度 は緩やかになり，振幅は大きくなる部分が確認された.またこの 変位の差は, First Sound にて最も顕著であり, 年龄による違 いが得られた CARTの結果と一致している.そのため生体にお いても，高齢者になるにつれ血管壁の変位が緩やかになる㑯 向にあると考えられ，CART により血管の柔軟性を推定できる と考えられる.

\section{6. まとめ}

模擬循環回路, 特性の異なる2種類のラテックス管を用いた 実験から，管特性の差が CART の差として表れる事が確認で きた.また，上腕動脈上の 2 籄所で音を計測するシステムを作 製し，CARTを求めたところ, 高龄になるほど CART が長くなる 傾向を確認することができた.以上の事から，CART を用いて 血管の柔軟性を推定できる可能性が示唆された。

\section{参考文献}

1 ）小沢俊：脈波速度に関する臨朱的，ならびに，実験的 研究一特に修飾する機能因子の検討. 脈管学,20:121 $-129,1980$.

2）道場信孝：血圧測定に必要な循環生理学の知識, 財団法人 ライフプランニングセンター

3）增田義昭：動脈硬化をいかに定量化するか, Arterial Stiffness 動脈壁の硬化と老化, No.2, 2002 